
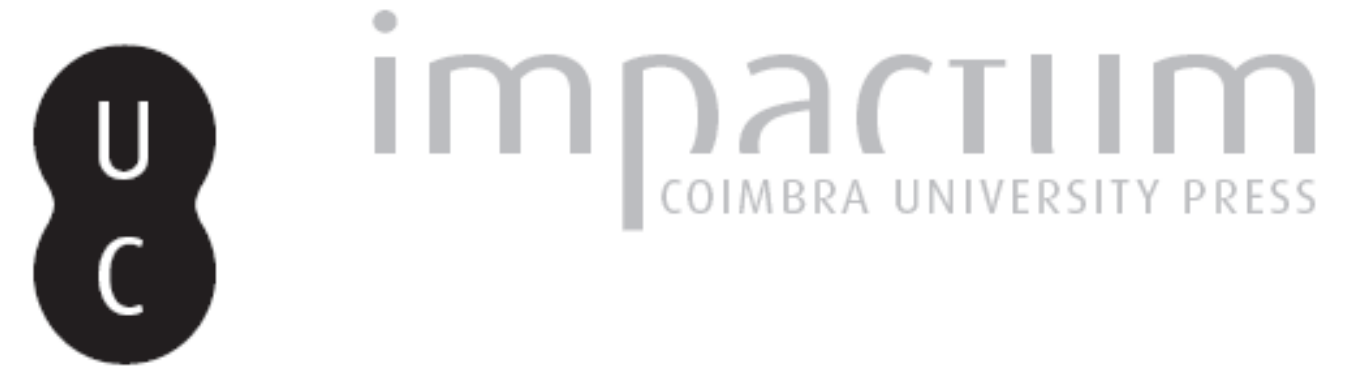

\title{
Soltería, mujer y litigiosidad en el cotidiano de la Edad Moderna: a vueltas con las palabras de matrimonio
}

Autor(es): $\quad$ Torremocha Hernández, Margarita

Publicado por: Imprensa da Universidade de Coimbra

URL persistente:

URl:http://hdl.handle.net/10316.2/40681

DOI:

DOI:https://doi.org/10.14195/0870-4147_47_8

Accessed : $\quad$ 26-Apr-2023 11:44:05

A navegação consulta e descarregamento dos títulos inseridos nas Bibliotecas Digitais UC Digitalis, UC Pombalina e UC Impactum, pressupõem a aceitação plena e sem reservas dos Termos e Condições de Uso destas Bibliotecas Digitais, disponíveis em https://digitalis.uc.pt/pt-pt/termos.

Conforme exposto nos referidos Termos e Condições de Uso, o descarregamento de títulos de acesso restrito requer uma licença válida de autorização devendo o utilizador aceder ao(s) documento(s) a partir de um endereço de IP da instituição detentora da supramencionada licença.

Ao utilizador é apenas permitido o descarregamento para uso pessoal, pelo que o emprego do(s) título(s) descarregado(s) para outro fim, designadamente comercial, carece de autorização do respetivo autor ou editor da obra.

Na medida em que todas as obras da UC Digitalis se encontram protegidas pelo Código do Direito de Autor e Direitos Conexos e demais legislação aplicável, toda a cópia, parcial ou total, deste documento, nos casos em que é legalmente admitida, deverá conter ou fazer-se acompanhar por este aviso.

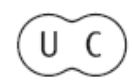




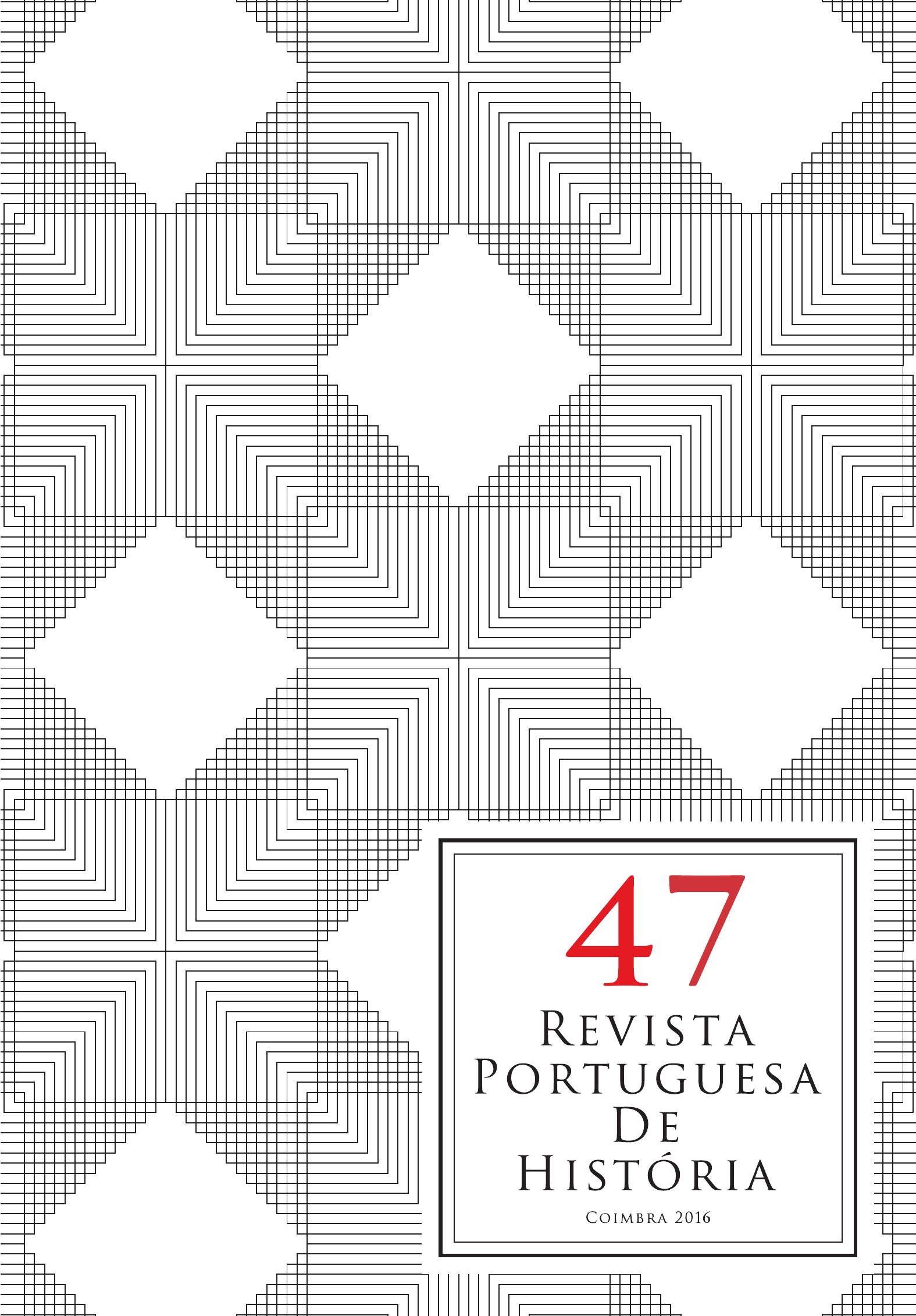




\title{
Soltería, mujer y litigiosidad en el cotidiano de la Edad Moderna
}

\author{
A vueltas con las palabras de matrimonio ${ }^{1}$
}

\section{Spinsterhood, Women and Litigiousness in the daily Life of the Early Modern Period. Around the Marriage Vows}

\author{
Margarita TORREMOCHA HernÁNDEZ \\ Universidad de Valladolid \\ torrem@fyl.uva.es
}

Texto recebido em / Text submitted on: 23/01/2016

Texto aprovado em / Text approved on: 22/06/2016

Resumo:

Tras la regulación del sacramento del Matrimonio en el Concilio de Trento, la práctica de dar palabra de casamiento pervivió en la sociedad castellana. Cuando alguno de los dos implicados se negaba a cumplirla el asunto se llevaba a los tribunales eclesiásticos y reales ordinarios. A través del relato de vida de un letrado, de una autobiografía concreta, en un ejercicio de microhistoria veremos cómo estas relaciones entre solteros, con o sin palabra, forzaron las vidas de hombres y mujeres a la hora de tomar estado.

Palavras chave:

Soltería; Mujer; Palabras de casamiento; Historia social.
Abstract:

The practice of 'giving word of marriage' survived in Castilian society after the regulation of the sacrament of Matrimony at the Council of Trent. Ecclesiastical and ordinary Royal Courts resolved situations in which one of the two involved refused to fulfil that promise. Through a lawyer's autobiography, in a micro history exercise, we can see how relationships between unmarried people, forced the lifes of men and women at the time of getting married.

Keywords:

Single state; Woman; Wedding words; Social History.

${ }^{1}$ IP del Proyecto HAR2012-31909, financiado por el Ministerio de Economía y Competitividad. Proyectos de Investigación Fundamental. VI Programa Nacional de Investigación Científica, Desarrollo e Innovación Tecnológica, 2008-2011. 
R.L. Kagan definió a la sociedad castellana de la Edad Moderna como una sociedad de pleiteantes ${ }^{2}$. La conflictividad general en toda colectividad tenía en este reino una tendencia a llegar hasta los tribunales, a pasar del conflicto al litigio, y a esta propensión no fueron ajenas las mujeres ${ }^{3}$.

No pretendemos realizar un análisis cuantitativo de la presencia de las mujeres en los tribunales reales (fuesen en materia civil o penal) o eclesiásticos, en esta etapa de multiplicidad de jurisdicciones privativas. Tampoco tenemos la ambición de establecer una tipología delictiva que afectase especialmente como víctima a la mujer. Nuestro objetivo es detenernos a examinar, desde la perspectiva de la microhistoria, uno de los asuntos que de forma más cotidiana llevó a las mujeres a reclamar judicialmente sus derechos ${ }^{4}$. Siendo lo común que estas promovieran judicialmente causas para protegerse de atropellos de esta sociedad jerárquica, el requerimiento al que atendemos es una demanda de mujeres a hombres: el cumplimiento de las promesas o palabras de matrimonio, en este caso con unas características especiales.

Para ello, hemos tomado como referente una documentación muy concreta; una fuente autobiográfica. La vida de un varón, un letrado, jurista reconocido por sus escritos ${ }^{5}$ y sus cargos al servicio del rey en los tribunales. Vida y Memorias del Ldo. D. Gregorio de Tovar, cavallero natural de Valladolid, Fiscal y oidor que fue de esta Chancillería de la Audiencia de la Coruña, y del Real Consejo de Órdenes, antecesor de la casa de Cancelada, que nació en 27 de Febrero de 1547 y murió en 9 de mayo de 1636 años en esta ciudad y yace en su capilla de Sta Ana de Nuestra Señora la Antigua ${ }^{6}$.

${ }^{2}$ R. L. Kagan, Pleitos y pleiteantes en Castilla, 1500-1700, Valladolid, 1991.

${ }^{3}$ En esta línea, O. Rey Castelao, recientemente ha puesto de manifiesto cuáles fueron los intereses que llevaron a las mujeres gallegas a sus tribunales señoriales y reales. "Las mujeres de Galicia ante los tribunales: la defensa de lo propio", en Procesos con nombre de mujer. La Justicia y los tribunales en la definición de la identidad femenina en la Europa Moderna, Historia et lus. Rivista di storia giuridica dell'età medievale e moderna, $\mathrm{n}^{\circ}$ 9, 2016.

${ }^{4}$ Análisis cuantitativos para fechas posteriores nos ofrecen José Miguel Palop Ramos, "Delitos y Penas en la España del siglo XVIII", Estudis: Revista de historia moderna, 22 (1996) p. 65-104. Pedro Ortego Gil, Entre jueces y reos: las postrimerías del derecho penal absolutista. Madrid, 2015.

${ }^{5}$ Nieto de Gregorio López de Tovar (Antonio Rumeu de Armas, "El jurista Gregorio López, Alcalde Mayor de Guadalupe, Consejero de Indias y Editor de Las Partidas", Anuario de Historia del Derecho español (1993-94) nº 63-64, p. 345-450) culminó su tarea en la edición.

${ }^{6}$ Biblioteca Nacional de España, Manuscrito 19.344. Se trata de un texto sobre el que estamos preparando en la actualidad una monografía, copiado por el historiador y paleógrafo Rafael Floranes. Los números que se recogen entre paréntesis en el texto corresponden a los folios de este manuscrito, y la grafía se ha respetado. 
El uso de las autobiografías o biografías como fuente para el estudio -como señaló Arnaldo Momigliano- se está instalando en el centro de la investigación histórica, y lo hace también como instrumento de la investigación social' . Una investigación que se puede desarrollar siguiendo el método historiográfico de Ferreroti, que considera que el relato de una vida ${ }^{8}$ nos permite descubrir lo cotidiano, las prácticas de vida abandonadas o ignoradas por las miradas dominantes, la historia de y desde los de abajo?.

En el caso de Gregorio Tovar, estamos ante un autor que cuando hace el relato de su vida quiere transmitir algunas cuestiones de su existencia, pero sobre todo de su linaje, de su limpieza de sangre, que tanto estima, de su formación, de su trabajo, de su ascenso social. De hecho, en las biografías se privilegia la dimensión pública sobre la privada. Nosotros aquí trataremos una cuestión muy accidental, fortuita, aunque no desdeñable, a la que el autor no atiende nada más que por obligación y en los límites necesarios. Ello nos permite salir de la individualidad de su autobiografía para plasmar una situación cotidiana en las vidas de hombres y mujeres, fundamentalmente en su soltería. Si en las biografías se privilegia la dimensión pública sobre la privada, como ocurre en esta, intentamos buscar en ella -en palabras de Bourdieu- el habitus de grupo frente el habitus individual. Vamos a dar protagonismo a algunas mujeres que se saltaron los usos socio-religiosos, que, por no responder al modelo establecido en principio estarían excluidas de toda biografía. Con ello, a través del discurso vital de un personaje de relevancia pública, atendemos a la realidad de sujetos de vida cotidiana ${ }^{10}$.

7 James Amelang, "Los dilemas de la autobiografía popular", Trocadero (2004) p. 9-17; "La autobiografía moderna entre la Historia y la Literatura", Crhonica Nova, 32 (2006) p. 143-157. Laura Scarano, "El sujeto autobiográfico y su diáspora: protocolos de lectura”, Orbius Tertius, (1997), 2 (4); Marie-Michèle, Produire sa vie: autoformation et autobiographie, Édilig; Montréal: Éditions Saint-Martin, 1983; Gaston Pineau and Jean-Louis Le Grand, Les histoires de vie, Presses Universitaires de France 1993; Gastón Pineau, "As histórias de vida como artes formadoras da existencia", Tempos, narrativas e ficções: a invenção de si. Porto Alegre, EDIPUCRS (2006) p. 41-59.

${ }^{8}$ Por relato de vida (story life) entendemos la utilización del relato personal para realizar un acercamiento y valoración de su entorno social. Fortunato Mallimaci and Mónica Giménez Béliveau. "Historias de vida y método biográfico, Estrategias de investigación cualitativa, 2006, p. 175-212.

${ }^{9}$ Franco Ferrarotti, "Las historias de vida como método", Convergencia: Revista de ciencias sociales, $n^{\circ} 44$ (2007) p. 15-40.

${ }^{10}$ Pierre Bourdieu, "La ilusión biográfica”, Historia y fuente oral, nº 2 (1989) p. 27-33. 
El objetivo del letrado, a través de este relato autobiográfico, no fue el de atender a cuestiones personales ${ }^{11}$, ni mucho menos a aquéllas que de alguna manera podían dejar una mala impresión de su persona, para la que él mismo no escatima alabanzas en uno u otro momento de su autobiografía. De hecho, la propia selección de las cuestiones a relatar ya introduce un factor de subjetivismo en el texto. No obstante, algunas se vieron mezcladas con su profesión y le llegaron a condicionar sus ascensos, por lo que se vio precisado a dejar constancia de ellas; sin extenderse en su consideración, más allá de lo necesario.

Así pues, este jurista, de una familia de juristas, que relata cómo fue consiguiendo premios en la administración, en concreto en la de Justicia, al servicio de la monarquía hispánica, nos aporta datos de su relación con una serie de mujeres cuando él estaba libre de ataduras conyugales.

\section{“...hallando anchurosa entrada a la deshonestidad de sus apetitos, no quieren venir al yugo del matrimonio" 12}

Poco nos hemos preocupado los historiadores por la vida en soltería, no tratando prácticamente este tema más allá de las aportaciones que se han hecho desde el punto de vista demográfico y biológico. Tampoco es generosa la literatura que al respecto podemos encontrar de los coetáneos, pues al no considerarse esta fase vital como un estado sino como una etapa de tránsito, no recibió apenas atención. Pero sin duda, el ejemplo de Gregorio Tovar, redactado por él mismo puede ser bueno. Fue un hombre que gozó de su etapa de soltería, que para él tuvo lugar no a lo largo de toda su mocedad, sino que la identifica con un periodo concreto que va desde el momento en que contó con un oficio en el servicio a la Monarquía en los tribunales, y se pudo independizar, salir de la casa de su padre, contar con una vivienda digna heredada de su tío Hernando de Tovar, y sobre todo con un trabajo como Fiscal en la Chancillería. Tal cargo había estado desempeñado antes por su progenitor, pero el Rey había tenido a bien dejarlo en sus manos y pagar a ambos, hasta que su padre muriera. Así, entre sus escasas observaciones sobre su vida personal está la manifestación de su contento por cómo supo disfrutar de este tiempo:

${ }^{11}$ No obstante, es posible aventurar muchas cuestiones personales, tanto por lo que dice como por lo que oculta. Margarita Torremocha Hernández, "Familia y paternidad, en la "historia de vida" de un letrado (s. XVI-XVII)", Gloria Franco (Coord.), Caleidoscopio de la vida cotidiana, Logroño, 2016, p. 125-147.

${ }^{12}$ Martín González de Cellorigo, Memorial de la politica necessaria, y vtil restauracion à la republica de España, y estados de ella, y del desempeño vniuersal de estos reynos, dirigido al rey don Philippe III..., Valladolid, 1992. 
“...y en este estado sin me casar, pasé ocho años con el gusto mayor de la tierra, sin tener hijos ni mas casa ni voluntad que sola la mia" (fol. 51).

Es pues una soltería buscada y no obligada como la que tuvieron que soportar otros varones por cuestiones económicas ${ }^{13}$. Él se independizó en su primer año de trabajo y contaba, además con la vivienda heredada en la calle de Santa Clara, junto al hospital vallisoletano de la Quinta Angustia.

"A ella me fuy el dicho dia, la qual halle a mi propósito, y como siendo solo y por casar pudiera desearla: llebé a ella razonables aderezos y los que me eran forzosos para en tiempo de verano e invierno, á donde siempre tube dos muy hermosos cavallos, que abia pocos tan buenos en Valladolid, dos lacayos, tres pajes, y dos criadas... (fol. 51)".

Se acomodó pues con tanto agrado a la soltería, entendida como vida de total independencia y libertad, que incluso dice en qué día accedió a ella. Nada menos que el de San Lucas de 1581; la jornada en que los escolares iniciaban el curso y comenzaban a poblar Valladolid, y sus calles, posadas, hornos, tabernas, librerías, etc. se llenaban de otros muchos mozos solteros, libres e independientes de sus padres y tutores ${ }^{14}$.

En la práctica, la soltería tenía entre los varones, en esta sociedad misógina, muchos seguidores, pero sin embargo, desde el punto de vista teórico, tuvo significativos detractores en esta época de arbitristas ${ }^{15}$. La búsqueda del aumento de población para el reino chocaba con el gusto por la soltería. Como ya analizó el arbitrista Martín González de Cellorigo (abogado de la Real Chancillería), con el que bien pudo coincidir en Valladolid Gregorio Tovar, no tomar estado no era bueno para la sociedad ${ }^{16}$. Sin embargo, este escritor no admitía que

${ }^{13}$ Manuel Urí-Martín. “Crisis y arbitrismo: Quevedo y el pensamiento económico español del Siglo de Oro", La Perinola. Revista de Investigación Quevediana, 2 (1998) p. 286.

${ }^{14}$ Margarita Torremocha Hernández. La vida estudiantil en el Antiguo Régimen, Alianza editorial. Madrid. 1998; "Ciudades universitarias y orden público en la Edad Moderna”, Cuadernos de Historia Moderna. Anejo III. Serie de monografías. Ingenios para el mundo: sociedad, saber y educación en la Edad Moderna. Universidad Complutense de Madrid (2004) p. 137-162.

${ }^{15}$ Como ha señalado J.I. Gutiérrez Nieto, existió un arbitrismo social, preocupado por la despoblación que causaba el descenso de matrimonios, que llevó a intentar corregir la tendencia de los varones por prolongar su soltería. "El pensamiento económico y social de los arbitristas", José Larráz, La época del mercantilismo en Castilla (1500-1700), Madrid, 1963, p. 88.

${ }^{16}$ Adriano Gutiérrez Alonso and Francisco José González Prieto and Sonia Serna Serna. “Autobiografía" del arbitrista Martín González de Cellorigo", Boletín de la Institución Fernán González (2008), 87, n² 237, p. 467-507. 
eran los varones los que apetecían esta libertad, sino que defendían que se daba la soltería masculina porque las mujeres la fomentaban -probablemente sin saberlo- con una serie de comportamientos todos ellos reprochables. Las casadas y por tanto adúlteras, de manera especial, porque además de engañar a sus maridos hacían que los otros varones no tuvieran necesidad de casarse para satisfacer sus necesidades sexuales, pero también lo hacían mozas casaderas, que estando en esta situación no contaban con dote o tenían otros problemas para llegar al matrimonio.

En su caso el disfrute de su prolongada soltería parece estar en relación con la costumbre de tantos castellanos - a juicio de los extranjeros que hablan de ellos- que alargan todo lo que podían el momento de recibir el sacramento del matrimonio ${ }^{17}$. De hecho, aprovechando que dispone de una casa heredada, además en Valladolid, la ciudad en que siempre había vivido y en ese momento trabajaba como Fiscal de la Real Chancillería, se dedicó a gozar de los placeres de la mocedad y la soltería. Sin tener que sujetarse a nada, sin gastar más que en lo que quería, sin verse desbordado por esos desmesurados desembolsos femeninos, que los hombres temían, por la liberalidad en disipar que usaban las mujeres propias ${ }^{18}$.

Solo la muerte de su padre, y la constancia que no podía seguir negando, de que su edad le pondría ya problemas para garantizar una sucesión legítima a su linaje le hizo cambiar. No en vano su familia andaba escasa de efectivos, pues su hermano mayor había muerto dejando solo un hijo, y la pertenencia al clero del resto de los varones le constreñía a no desamparar a la familia.

"y ansi visto ya que mi Padre era muerto y que mi sobrino era solo me parecio era razon y tiempo de me casar y ansi me determiné a ello, lo qual muchos años antes havia reusado y aunque se me havian ofrecido muchos casamientos y ricos siempre lo reuse" (fol. 63).

En definitiva, se casó ya con 41 años, y esta tardanza le pesó posteriormente por ser viejo con hijos pequeños. No obstante, su prolongada vida le permitió verlos acomodados y con descendencia a unos e, incluso, morir a otros ${ }^{19}$. Pero, en general, en la tendencia misógina de la sociedad patriarcal de la época, el matrimonio era un mal menor ("pero no hay casa sin ese mal” decía el refrán),

${ }^{17}$ M. Torremocha, La Mujer Imaginada. Visión literaria de la mujer castellana en el barroco. Editorial abecedario. Badajoz. 2010.

${ }^{18}$ María Antonia Bel Bravo, Mujer y cambio social en la Edad Moderna. Madrid, 2009, p. 111 y ss.

${ }^{19}$ Margarita Torremocha Hernández. "Familia y paternidad, ...”, cit. 
eso sí, para toda la vida, por ello si se asumía tarde sería más llevadero. La elección de la mujer adecuada era una materia difícil, aunque no fue esa cuestión que a él le preocupara aparentemente, pues conocía muy bien lo que buscaba en una mujer. Sus preferencias no estaban en lo físico, ni en lo espiritual, ni siquiera en materia de modales y comportamientos. Buscaba una mujer de sangre limpia que no obstaculizase sus progresos y los de sus hijos.

De ahí, que en su larga soltería, etapa previa al matrimonio, no exista un periodo de noviazgo. Es esta otra acepción que no cuenta con un análisis historiográfico, probablemente porque es un concepto de la etapa contemporánea, al que intentamos dotar de contenido en la Edad Moderna ${ }^{20}$. En su caso, Gregorio conoce a la mujer con la que va a compartir el resto de su vida el mismo día de los esponsales. No obstante, esa etapa previa al casamiento no es una fase de celibato.

\section{“...sin me pedir palabra antes que conmigo se rebajase..."}

Como tantos hombres, antes, en su disfrutada soltería, no vio razón para renunciar a su trato con las señoras. El varón, a diferencia de la mujer, si no había contraído matrimonio contaba con mucha permisividad en sus actuaciones, pues no siendo casado sus hechos en materia sexual no atraían la condena social, como lo hacían con las féminas. La visión que sobre esta materia tenía la sociedad del Siglo de Oro, incluso el peso de la ideología eclesiástica -analizada a través de manuales de confesores y tratados de teología- en las mentalidades colectivas era mucho más relajada en lo que tocaba a los códigos de honor y a la correcta moral sexual ${ }^{21}$. No obstante, aunque esto fuera así, no considera necesario hacer mención explícita de esta parte de su vida cuando escribe su autobiografía, teniendo en cuenta que lo hace siempre con un cuidado orden cronológico. Pero tal relación no se recoge en su historia de vida cuando por

${ }^{20}$ Entre las pocas aportaciones así concebidas, Marta Ruiz Sastre and Alonso M. Macías Domínguez, "Cuando el amor desaparece. Ruptura de noviazgo y separación matrimonial en el Antiguo Régimen. El caso del arzobispo de Sevilla", Eliseo Serrano (Coord), I Encuentro de Jóvenes investigadores en Historia Moderna, Zaragoza, 2013. Y para un periodo posterior: Manuel Hernández González, "Mujer y noviazgo en Canarias durante el siglo XVIII", Tebeto, Anuario del Archivo Histórico Insular de Fuerteventura, (1996) n ${ }^{\circ}$ 9, p. 11-24 o Ma Molina Gómez. "Juventud y sexualidad: actitudes y conflictos entre" mozos" y" doncellas" en el marco social y familiar. Algunos ejemplos del siglo XVIII en el suroeste de Albacete", Nuevo Mundo Mundos Nuevos (2008).

${ }^{21}$ En teoría, leyendo por ejemplo a Farfán en su obra Tres libros contra el pecado de la simple fornicación, (1585) también el varón estaba obligado a cuidar su sexualidad durante la soltería. 
tiempo le corresponde, sino cuando le obligan sus problemas en su vida laboral y personal.

El asunto de "faldas" le llegó en 1582 -cuando él todavía soltero ya tenía 35 años- por una enemistad entre varones, no por cuestiones particulares sino de origen profesional. La causa por la que se destapa su conducta

“...fue que vino á aquella audiencia por Presidente de ella el Dn. Francisco Hernandez de Lievana ${ }^{22}$ : el qual abia sido en sus principios fiscal de Valladolid juntamente con mi Padre, y sucedió que no se llebando bien, hubo entre ellos algunas diferencias" (fol. 51 v.).

El letrado que entonces llegaba como Presidente a la Chancillería antes había sido en ella fiscal, pero dejó su cargo para pasar a ser también fiscal en el Consejo de Indias. Entonces, el padre de Gregorio, llamado Tomás, a su vez pasó de ser fiscal en la sala de lo criminal a la sala de lo civil, y allí tuvo que seguir una causa de hidalguía, y mandar diligencieros a un pueblo de Salamanca, donde tomaron declaración como testigo al anciano padre de su antiguo compañero.

“...y en las preguntas xenerales respondiendo a ellas, dijo ser pechero, y de casta y generación de pecheros. Visto esto por su hijo, entendio haverse hecho esto con malicia de mi Padre, y juntando esta causa de agrabio suyo con otras que él decía tenia de mi Padre, siempre le fue enemigo; y ya que no se pudo vengar de el, buscó en qué me hacer á mi daño..." (fol. $\left.51 \mathrm{v}^{\circ}\right)$.

Verse descubierto en unos orígenes que él negaba, fue un agravio para Hernández de Liébana, que además estaba seguro que hasta allí no se había llegado por la casualidad, sino por el afán de perjudicarle. Por eso, no dudó en proceder con la misma malicia, para devolver el ataque, ya no a Tomás Tovar, que estaba "jubilado", sino a su hijo. Su punto débil estaba en esa vida de soltería, que le había llevado a vivir diferentes relaciones censurables, social y -podía ser- que jurídicamente.

${ }^{22}$ Manuel Rivero Rodríguez, "El dilema de los letrados, servir al Rey y a la fe: Francisco Hernández de Liébana”, Librosdelacorte.es, Monográfico 1, (2014) ISSN 1989-6425. En este artículo se le califica de cristiano viejo, estudiante de Salamanca, y colegial en el Mayor de Cuenca de esta misma Universidad. También se dice de él "afable y de buen carácter", aunque en nada de esto esté de acuerdo Tovar. Su nombramiento para la Chancillería de Valladolid fue en 1556. Entonces fue cuando coincidió con su padre, después de muerto Niño, su valedor en la corte, y donde estuvo hasta 1558, en que se fue como Fiscal del Consejo de Indias. 
“... buscó en qué me hacer á mi daño: y fe que supo estaba en esta ciudad de Valladolid una señora llamada $D^{\mathrm{a}}$. Beatriz de Castro, hija de el Ldo. Villabeta Alcalde mayor que fue por S.M. en el Adelantamiento de Campos, la qual tenia de mi queja de que persuadiéndose ella a me dar gusto, yo me casara con ella, sin me pedir palabra antes que conmigo se rebajase" (fol. 51 vo -52).

En definitiva, encontró una mujer que tuviese asuntos pendientes con él. Que reclamase judicialmente matrimonio al fiscal de la Chancillería. Ella, que no se puede decir que hubiera actuado engañada, no había sido previsora, ni procedido del modo convencional, y no le había exigido previamente palabra de casamiento ${ }^{23}$. La palabra, hacía contrato y el contrato obligaba a ser cumplido bajo pena de pecado mortal. Como señalaban los tratadistas, de existir promesa "por ambas partes", palabras de futuro mutuas o esponsales, él quedaba obligado. Si solo uno había dado las palabras, y el otro no, aunque se supone que había aceptado, el pecado era venial, y las consecuencias otras ${ }^{24}$.

Como falta esta palabra, la mujer, ni por su cuenta, ni ayudada por los varones de su familia, actúa para mover los resortes que le podía proporcionar el amparo institucional de la justicia, aunque el propio Gregorio reconoce que había quedado malparada ("la qual tenia de mi queja"). A buen seguro, que la valoración de las escasas posibilidades de conseguir una reparación ante la justicia, lo que al mismo tiempo daría una publicidad no querida al asunto, les llevó a renunciar a cualquier tipo de actuación y con ello a cualquier satisfacción. Sin embargo, no estaría muy oculta, sí pudo saber de esta relación un recién llegado a la villa, aunque con conocidos en ella.

Pero, ¿quién era Beatriz de Castro? Como era propio en este jurista y en esta sociedad, a pesar de ser una mujer con la que no quería tener más que una relación sin ataduras, pero continuada, buscó galanura y calidad. En cuanto a la belleza, él mismo la define como afortunada "... siendo en gran estremo hermosa y gentil...” (fol. 56). En lo que atañe a su condición social, tampoco era poca, "...por que era muger principal y honrrada...", tanto era así que aunque él dice no haberlo conocido en su momento, eran familia, “...y que ella era mi pariente en el quarto grado, lo que hasta aquéllos días siempre yo

${ }^{23}$ Francisco Javier Lorenzo Pinar. Amores inciertos, amores frustrados, (conflictividad y transgresiones matrimoniales en Zamora en el siglo XVII), Zamora, 1999; "Conflictividad social en torno a la formación del matrimonio (Zamora y Toro en el siglo XVI)", Studia Historica: Historia Moderna (2009) 13.1.

${ }^{24}$ Pedro de Ledesma, Adicciones a la primera parte de la Summa, en la cual se cifra y suma todo lo que toca y pertenece a los sacramentos, con todos los casos y dudas morales resueltas $y$ determinadas. Tratado del Sacramento del Matrimonio, Lisboa, Pedro Crasbeeck, $1617\left(1^{\circ}\right.$ ed. 1598). 
abia ignorado" (fol. $\left.52 \mathrm{v}^{\circ}\right)$. Así pues, una mujer con la que estaba emparentado, incluso debía haber pedido dispensa matrimonial de haber querido contraer matrimonio con ella.

Admite asimismo, que la igualdad social en la que se movían podía haber sido el detonante que a Beatriz le hubiera hecho creer que, aun sin palabras de casamiento, acabaría Gregorio por casarse ${ }^{25}$, pues “...decía ella que siendo como decía era tan buena como yo, que por el daño hecho me havia de casar con ella" (fol. 56). La mujer no cedió por engaño, sino segura de sus posibilidades, pero en definitiva, sí que se puede decir, siguiendo la terminología de M.L. Candau, que sus amores fueron "torpes" 26 .

No sabemos cómo el Presidente de la Chancillería tuvo conocimiento de este trato con mujer soltera. Quizás porque era más público de lo deseado. Pero no perdió el tiempo y ofreció a esta su apoyo para llevar una denuncia adelante. Faltaba el juramento porque no hubo palabra que como tal promesa hecha hubiera tenido el valor de contrato, similar al propio matrimonio (aunque no al sacramento) ${ }^{27}$. No obstante, en ausencia de compromiso verbal estaba la "evidencia" del trato carnal ${ }^{28}$. No hubo palabra de matrimonio pero este -elemento fundamental- se consumó por cópula carnal. Sin embargo, la familia de la joven, familia también de Gregorio, debió considerar que carecía de razones y argumentos legales o pruebas y por ello no llevó el asunto a los tribunales. Cuando tienen certeza de que cuentan con el interés y el apoyo del Presidente y que su querella puede ir adelante es cuando actúan ${ }^{29}$.

${ }^{25}$ Antonia Fernández Valencia, "Deseo y honra de las mujeres en la España Moderna. Ficción y reclamaciones del amor burlado", De la Pascua, M.J. et al. (eds.), Mujer y deseo: representaciones y prácticas de vida, Cádiz, 2004, p. 485-499; F.J. Lorenzo Pinar, “Actitudes violentas en torno a la formación y disolución del matrimonio en Castilla durante la Edad Moderna", en Fortea, J.I. et al. (eds.), Furor et rabies. Violencia, conflicto y marginación en la Edad Moderna, Cantabria, 2002, p.159-182; Margarita Ortega López, "Protestas de las mujeres castellanas contra el orden patriarcal privado durante el siglo XVIII", Cuadernos de Historia Moderna (1997) 19, p. 65-90.

${ }^{26}$ M. Luisa Candau. "El matrimonio presunto, los amores torpes y el incumplimiento de la palabra: Archidiócesis de Sevilla, siglos XVII y XVIII", Padres e hijos en España y el mundo hispánico: siglos XVI y XVIII. Visor, 2008.

${ }^{27}$ Bartolomé Bennassar recoge la idea del matrimonio como contrato en todos los grupos sociales, basándose en el estudio de los matrimonios celebrados en la localidad de Villanubla, cercana a la capital vallisoletana. Los españoles. Actitudes y mentalidad. Barcelona, 1976.

${ }^{28}$ Isidro Dubert. "Los comportamientos sexuales premaritales en la sociedad gallega del Antiguo Régimen”, Studia Historica: Historia Moderna (2009) 9.

${ }^{29}$ Juan García González, "El incumplimiento de las promesas de matrimonio en la Historia del Derecho Español”, Anuario de Historia del Derecho Español, 23 (1953) p. 611-642. 
“...y como el Presidente supo esto, la enbió a llamar á su casa, y benida la persuadió á que se querellase de mi al Rey, y que pidiese se le cometiese á él la información, y que él la haría de manera que me obligase, aunque no la hubiese dado palabra de casamiento, a que yo me casase con ella. Visto por ella este ofrecimiento y el ser hecho por persona tal, le acetó y hizo como se le havia dicho; y luego se fue â Madrid, y se quejó de mi en el Consejo, y trujo cedula Real cometida a este Presidente, para que hiciese la información..." (fol. 52).

Gregorio al ser un varón soltero aunque como es lógico no hubiera mencionado este episodio en su autobiografía si no hubiera sido expuesto por la querella, no ve necesidad en hacer ocultamiento de unos actos que a él no le deshonran, que podrían incluso caer dentro del ámbito de la práctica del galanteo, que tanto frecuentan los varones en su soltería y que algunos no abandonan en su vida de $\operatorname{casado}^{30}$. De hecho, la relación, sin ser amancebamiento tuvo carácter permanente. No era notoria, pero no se disimuló a los ojos de los vecinos. Esto permitió contar con una serie de testigos indirectos que confirmaron que la mujer no era mujer pública, que sólo le recibía a él:

“...y los que halló, y mas decían, era que sabia abia parido, y que creían y tenían por cierto era de mi; por que era muger principal y honrrada, y que ninguno abian sentido entrar en su casa sino yo, y que era publico trataba yo con ella" (fol. $\left.52 \mathrm{y} \mathrm{v}^{\circ}\right)$.

Es fácil pensar que ante esto, tanto ella como sus parientes y vecinos, pensaban que el final sería el matrimonio de ambos. Si ella tomaba estado no quedaba deshonrada. Si lo haría si él públicamente se negase a contraer nupcias o lo hacía con otra.

Tenía él un testigo especial, que consideraba que era de suficiente peso para cubrir su actuación:

“...fue de su malicia y de mi ignocencia buen testigo Dn. Alonso de Mendoza Abad de Valladolid, el qual no una sino muchas veces la oyó decir, que nunca yo la abia dado palabra de casamiento ni ella jamás me la pidió, sino que decía ella que siendo como decía era tan buena como yo, que por el daño hecho me havia de casar con ella" (fol. 56).

\footnotetext{
${ }^{30}$ Margarita Torremocha. "El galanteo. Una práctica amorosa española vista desde Europa (siglo XVII)", Historia y género: imágenes y vivencias de mujeres en España y América (siglos $X V$-XVIII), Málaga, 2007.
} 
Pero además, admitiendo ambos que no había mediado palabra de casamiento aún quedaba pendiente la probanza de este delito. No era fácil de hacer, como no los son los delitos que englobamos contra la moral sexual, fundamentalmente el adulterio, pero también todos los demás ${ }^{31}$. La prueba legal tiene que dejar paso en la mayor parte de los procesos a la prueba de indicios, muy al contrario de lo que se recomendaba en las Partidas, que tan bien conocía el autor. La verdadera prueba era ser pillado in fraganti, pero el letrado que había sido cuidadoso en no dar palabra de casamiento también lo fue en este detalle.

“...era publico trataba yo con ella. Pero no hubo jamas testigo de nos ver juntos en la cama ni en otra parte sospechosa" (fol. $52 \mathrm{v}$ ).

El trato era innegable, y en el tiempo de sus relaciones, como hombre de letras había mandado incluso algunas epístolas a la mujer, y esta las conservaba, pues pudo aportar nada menos que medio centenar, en las que tampoco se prometía nada para el futuro.

"Presentó tambien casi cinquenta cartas mias, y en ninguna de ellas hubo ni se alló palabra que me dañase" (fol. $52 \mathrm{v}$ ).

Ella era soltera, estaba pues en un estado transitorio ${ }^{32}$. Pero siempre creyó que finalmente podía casarse con el fiscal Gregorio Tovar, porque la relación era conocida y porque, como mujer, no perdía la honra por ello, siendo además un asunto privado. Si lo haría no solo cuando se le diera publicidad, sino cuando el varón dejase claro que no pensaba casarse con ella. Pero él no se movía en el escenario de los afectos, ni de las preocupaciones femeninas, que atañen a la mujer, que por su comportamiento queda deshonrada y en los márgenes de la sociedad.

Él, libre de ataduras matrimoniales, y no pensó que guardadas estas precauciones jurídicas tuviera nada de qué inquietarse, hasta que otro jurista enemigo facilitó el camino a la denuncia de la mujer. Pero la autoridad del Presidente de tan alto tribunal era suficiente para amedrentarse e intentar solventar el asunto antes de que para él fuese peor. Usó sus contactos e influencias e intentó evitar un juicio.

${ }^{31}$ María José Collantes de Terán, "El delito de adulterio en el derecho general de Castilla", Anuario de Historia de Derecho Español, nº 66 (1996) p. 201-228.

${ }^{32}$ Francisco Chacón Jiménez and Juan Hernández Franco, Espacios sociales, universos familiares. La familia en la historiografía española, Murcia, 2007, p. 202. 
“...lo qual luego que lo entendí, me fuy y partí para Madrid, y antes que allá llegase, supe como el Presidente de el Consejo Real Pazos, estava en el Escorial por ser tiempo de la Semana Santa; fuyme allá; el qual me acogió muy bien, y traté con él de a lo que yba y del agrabio que el Presidente de Valladolid me hacia" (fol. $52 \mathrm{v}^{\mathrm{o}}$ y 53 ).

$\mathrm{Su}$ entrevista con el Presidente del Consejo fue muy tranquilizadora. Su opinión fue de hombre más que de jurista. Gregorio no se vio precisado a negarle nada, porque siempre se sintió seguro y respaldado por no haber dado palabra, y por su parte Beatriz así lo admitió en todo momento

“... y confesándole la pura verdad de lo que entre aquella señora y yo havia pasado por sus puntos y tretas, me respondió estas palabras (heme olgado de oyr a vmd, y no tenga pena, que pues no hubo palabra de casamiento, y me dice que ella ansi lo dice y confiesa, todo lo demas fue de buena voya; y no es bien crean las mugeres que en ser ruines les aguarda luego buen marido; yo le aseguro de todo daño: Pero será bien darla algo con que sea ayudada y decirla- Vade in pace con esto" (fol. $52 \mathrm{v}^{\mathrm{o}}$ y 53 ).

Como hombres resolvieron el asunto, pues solo las mujeres eran ruines, y entendían ellos que en la pérdida de su honra influía su deseo de conseguir un determinado y ansiado matrimonio. En consecuencia, la indigna perjudicada, había quedado embarazada y sin marido. Su gestación era un rumor (con el peso que la voz pública tenía en esta sociedad), y para no darle más pábulo ella dejó su casa; “...se havia recogido a un monasterio, queriéndose quedar en él por monja aunque por entonces se estaba en su traje y havito seglar y de dama" (fol. 52). Buscó un convento pues el único recurso para su situación era la reclusión, como para tantas otras mujeres, aunque no para consagrarse, sino como resguardo ante una situación que socialmente le perjudicaba mucho. Parece pues que no pretende profesar. No estaba en condición de novicia ni de religiosa. Está recluida, como tantas y tantas mujeres que tomaron los espacios conventuales como refugio ante la imposibilidad de casarse, ante la deshonra, ante el abandono de sus maridos, o por castigo legal o social. Además, profesar requería una dote que quizás no tenía, y puede que aun tuviera esperanza de poder solucionar su problema, contraer nupcias y, como consecuencia de tomar estado, encontrar un lugar en su sociedad.

No estaba dispuesto Gregorio Tovar a consentir en un matrimonio forzado por el Presidente de la Chancillería, pero la publicidad de los hechos, y la presión de algunas personas le llevaron a ceder y conceder a Beatriz Castro una compensación económica, para que esta se apartase de la denuncia interpuesta. 
Sus hermanos defendieron sus derechos y se buscó como mediador a una persona solvente, con autoridad y relevancia en la ciudad como era "Gonzalo de Villasante Arcediano de Valladolid ${ }^{33}$, que tambien era su deudo de ella; y se le pareció bien según me cargó la mano; pero por acabar con esta pesadumbre, le di todo lo que dijeron la diese" (fol. 53).

Económicamente se vio perjudicado, pues aunque en su relato quiere hacer ver que lo tenía todo solucionado, tuvo que darle nada menos que mil seiscientos ducados, "y con esto ella y sus hermanos se apartaron de la querella, y se fue en casa de una hermana suya, que vivía en la villa de Frómista; y allí se estuvo algunos días" (fol. 53).

La mujer, resarcida ya del daño que se le había hecho, deja el convento. No necesita esta reclusión. Sobre todo porque el asunto ya es público.

“...en fin, como ya aquel mal christiano y ruin hombre de el Presidente de Valladolid ya la abia inquietado y sacadola de el Monesterio á donde ella estava con intento de se quedar allí monja y se viese ya fuera y publica su deshonestidad y mal hecho, que hasta entonces estava muy oculto y secreto, y se vio en libertad, propuso de no bolber mas al monesterio" (fol. 55).

La cantidad aportada la permitía afrontar su vida de otra manera: "y haviendose resuelto en esto, puso a sus parientes en nuebos cuidados de lo que harian de ella; en fin, pagando sus deudas y aiudando á el ajuar de su casa" $\left(\right.$ fol. $55 \mathrm{v}^{\circ}$ ). De hecho podía hacer frente a sus necesidades con el pico y dejar los mil ducados invertidos en un censo; "los otros mil ducados restantes en un censo á quinze mil el millar, y como yo la vi en esta resolución, les pedi que como aquel censo se havia de dar á otro, se me diese a mi, y que yo la pagaría 25 mil marabedis cada año; y ansi se hizo" (fol. 56).

Encaminada ya su situación,

“...sus deudos dieron luego orden como ponerla en casa de la Marquesa de Villamanrique; cuyo marido entonces yba por Virrey de Mexico: y la recibió por su dama de doze que con este nombre llevava a las Indias ${ }^{34}, \ldots$ En fin,

33 Juez y examinador Sinodal, Maestrescuela y Canónigo de la catedral de Valladolid. Constituciones sinodales hechas y promulgadas en el primer Sínodo que se celebró en la ciudad y obispado de Valladolid, 1634 (reimpresión 1803), p, 115 y 348.

${ }^{34}$ Blanca de Enríquez de Velasco obtuvo licencia para acompañar a su marido. Fechas de estancia (1585-90). Ella era sobrina del Virrey Martín Enríquez. En el artículo de Antonio Rubial García ("Las virreinas novohispanas. Presencias y ausencias", Estudios de Historia Novohispana (2014), 50, p. 3-44) se analiza entre otras las costumbres de estas mujeres y la práctica de hacerse acompañar de otras. 
ella pasó á Indias, y siendo en gran estremo hermosa y gentil, se le aficionó un caballero deudo de el Virrey, abiendose desposado con ella según dicen, murió ella..." (fol. 55).

Lo que sin duda más le molestó a Gregorio, fue que los varones de la familia de Beatriz acabaron disfrutando la suma que le había entregado a ella. Compensación que si seguimos sus palabras, casi literalmente, se hace por generosidad, pero que sin duda no tuvo más remedio que aportar esa cantidad para evitar la cárcel y garantizarse su tranquilidad en los tribunales, aunque no hubiera dado palabra de casamiento. Tras todo este episodio, finalmente añade, no sin ironía:

“...y gozan mi dinero los señores honrrados de sus hermanos, que la heredaron, que eran tan cortesanos viejos y de el palacio, que no haciendo de estas cosas caso alguno, embiavan a cobrar los tercios que corrian de el su dicho censo en tan guena guerra ganado. En fin, yo redimi este censo por me ber libre de ellos, y les di sus mil ducados y los embié con Dios" (fol. 55v $\mathrm{v}^{\circ}$.

Este caso concreto, que relata su protagonista, es un ejemplo más de la sexualidad y el comportamiento de los jóvenes y no tan jóvenes antes del matrimonio en la Edad Moderna. En su caso fundamentalmente tiene trato con una mujer de condición social pareja a la suya, pero sin que su comportamiento responda a la práctica arraigada, del amancebamiento, que hace que la relación estable sustituya al matrimonio, como ocurría de forma generalizada en esta época en algunas zonas rurales ${ }^{35}$.

Aunque Gregorio parece que hizo la elección de forma muy consciente, por su calidad y su belleza, que él mismo elogia, en su relato no existen referencias amorosas, sino interés y cálculo, en esta relación que se aborda muy conscientemente, buscando eliminar todo tipo de compromiso. En su historia de vida prima la "economía de sentimientos". No se habla por supuesto de la frustración de ella (quizás no la hubo dado que el problema se resolvió dentro de los parámetros habituales en su sociedad), del bloqueo de sus expectativas. Simplemente, no se la mienta.

${ }^{35}$ Algo parecido ocurre en la sociedad extremeña del siglo XVII, ya que la cohabitación sin unión sacramental era una costumbre arraigada que el control eclesiástico no logró evitar. "No podemos hablar de un pueblo rebelde, sino de unas gentes con fuerte apego a sus tradiciones que, a pesar de su ancestral origen, solían mantenerse vivas e incluso las aceptaban como base de su idiosincrasia histórica" (Isabel Testón Núñez, Amor, sexo y matrimonio, Badajoz, 1985, p. 39). 
Beatriz, sin embargo, creyó en todo momento que estas cualidades le permitirían llegar al matrimonio. En definitiva, unas mismas acciones, pero una diferente valoración social del comportamiento en unos y en otros ${ }^{36}$. La soltería no se podía vivir de la misma manera en el caso de los hombres y las mujeres. Para ellas no era libertad y goce, y cuando así lo vivían las consecuencias eran muy diferentes. Perder la honra les podía hacer perder su integración social. Cuando el caso tiene que ser llevado ante la justicia, entonces ya hay publicidad y el acuerdo más favorable, si se consigue, será fundamentalmente económico, que no era poco.

La pregunta ante este caso concreto es ¿qué diferencia hubiera habido en el caso de haberle dado palabra de casamiento? Buena parte de casos de incumplimiento de palabra terminan con un acuerdo económico en el ámbito extrajudicial, como ocurrió con este. Su conocimiento de la norma y el esmerado cuidado que tuvo en no conceder tal promesa ni verbalmente ni por escrito finalmente no le valió de nada. Un enemigo y la publicidad que a pesar de todo tuvo su relación fueron suficientes para que la mujer lograra una compensación económica, propia de relaciones bajo palabra. En cualquier caso, no podemos olvidar, que solo conocemos la visión parcial de uno de los implicados.

Igualmente, otra cuestión que no se debate queda desdibujada. El embarazo al que hacen referencia los vecinos y el supuesto hijo/a de ambos no aparece en esta cuestión. La deshonra es lo que se tiene que resarcir. En los pasos de Beatriz de Castro tampoco hay mención, ni cuando está recluida en el convento, ni cuando toma la decisión de irse con la Virreina, ni cuando muere. Sin embargo, años después, Gregorio Tovar deja constancia en su autobiografía de una hija natural que tuvo, aunque no lo precisa, parece ser que antes de casarse. Entonces ejerce un papel de padre que no había llevado a cabo aparentemente en momentos anteriores de la vida de su hija. Nada dice de quién es su madre, de tal manera que podemos pensar que fuera ella, como la relación más clara de soltería que se le atribuye.

Una sola mención en su autobiografía a su descendiente, fuera del matrimonio, que no se produce hasta 1603, veintidós años después de iniciar su vida independiente y sus más gozosos años de soltería. Entonces, Gregorio deja a los miembros de su familia, y se viene desde Galicia para ver profesar a su hija extramatrimonial.

\footnotetext{
${ }^{36}$ M. Pilar Molina Pérez, "Juventud y sexualidad: actitudes y conflictos entre "mozos" y "doncellas" en el marco social y familiar. Algunos ejemplos de siglo XVIII en el sur de Albacete", Mundos nuevos Nuevos Mundos (2008).
} 
"Dilatelo hasta entonces por causa de dar velo de monja en el monesterio de Sta Cathalina de Sena de Valladolid a Isabel mi hija natural, que se lo dio el dia de Sn. Agustín 28 de agosto de 603 que fue de los mas solemnes que jamás se vio: fue su madrina la Reyna nra. Sra. Muger del Rey Dn. Phelipe 3 la qual hizo el oficio de madrina suya llebandola en la procesión de la mano, y teniendo todo el tiempo que el darle el velo y el sermón duró, su cirio grande encendido en su mano, asistiendo por la parte de el Choro á aquel acto estando públicamente y descubierta y en cuerpo arrimada a la reja y dentro de el monesterio todas su damas e infinidad de señoras que alla dentro (abian entrado con la Reyna) en refitorio con las monjas y a costa de las monjas. Acá fuera en la Iglesia hubo mucho concurso de gente gran música y lo demas necesario y forzoso a tal acto tan autorizado con la presencia y madrinazgo de una Reyna de España" (fol. 157vo - 158).

El acto no pudo ser más principal, con participación de una reina que se movía cotidianamente por los conventos vallisoletanos en los años de la Corte del Pisuerga $^{37}$. La hija natural cuenta con la asistencia del padre, y no del resto de la familia que este ha creado a partir de su matrimonio, pero sin embargo si queda vinculada a sus tías, hermanas de su padre que llevaban tiempo en ese mismo convento. De hecho Lucía de Tovar fue priora en él entre los años 1623-162438.

Si su madre fue Beatriz de Castro, si se separó de ella al nacer, quién la crió hasta que entró en el convento que pudo ser mucho antes de esta profesión, son todos asuntos que desconocemos para este caso concreto. No entran en el relato de su vida ${ }^{39}$. Él tenía planificado un itinerario familiar distinto, en el que podía entrar una hija ilegítima pero no una mujer que no fuera la más conveniente para su progreso y el de su linaje.

\section{Otras relaciones "siendo mozo y por casar": "...que estas havian sido mugeres ordinarias de cuyo trato no podía haber escándalo"}

Pero, antes del matrimonio, no fue Tovar hombre de una sola mujer. Su vida profesional le enfrentó en otra ocasión a sus poco convenientes relaciones

${ }^{37}$ Margarita Torremocha Hernández. "La corte vallisoletana de Margarita de Austria", J. Martínez Millán, P. Lourenço (Eds.), Las relaciones discretas entre la monarquía Hispánica y Portuguesas. Las casas de las reinas (siglos XVI-XIX). V, Madrid, 2008, p. 1617-1642.

${ }^{38}$ Cándido Aniz Iriarte. 500 Años de Fidelidad. Convento de Santa Catalina. Caleruega, Burgos, 1988.

39 "Esta hija natural la llamaba él la Isabelica, y dice en otra parte que la avia tenido educando en el convento del Corpus de esta ciudad al cuidado de la Priora pagando a esta un tanto para sus alimentos". Rafael Floranes, Apuntes para la Historia de Valladolid (2). Consultado el 26/04/16. 
con las mujeres. De nuevo fue en los ambientes jurídicos de los letrados que pugnaban por obtener premios y cargos en la administración, y que para ello debían defender sus orígenes y limpieza de sangre, donde surgió el problema. Cinco años después del anterior episodio, en 1589, la Chancillería recibió como Visitador a Jerónimo de Manrique, obispo de Cartagena, personaje temido entre los que trabajaban en este tribunal. Curiosamente, este también tenía enemistad a la familia por la misma causa: la tarea que su padre Tomás de Tovar había llevado adelante como fiscal de lo civil, en el seguimiento de hidalguías. De hecho, con su labor se había probado nada menos que, este hijo de clérigo, tenía un bisabuelo que había judaizado (fols. 74-75).

Esta vieja razón, unida a otras causas más recientes y que habían corrido de su mano, le había enemistado claramente con el visitador, que cuando dio sus resultados acusó a Gregorio Tovar, por diversas faltas, tales como retrasos y ausencia de los tribunales cuando se tenían que sustanciar causas. El fiscal negaba las negligencias que se le atribuían en lo laboral. Pero, además se le hacía otra recriminación de carácter casi personal.

\begin{abstract}
"Aberiguase tambien contra el dicho Dn. Gregorio de Tovar que há vivido desonestamente dando mal exemplo tratando con tres mujeres siendo soltero, las dos de ellas solteras y la una traya pleyto en su sala, y la otra era casada y por esta razon vivía inquieta con su marido por lo qual le condenamos en tres años de suspensión del oficio que sirve de Fiscal" (fol. 77).
\end{abstract}

El visitador llegó a la Chancillería buscándole, y el resultado de sus conclusiones podía ser muy duro para su vida profesional y la consecución de los ascensos que esperaba. Es curioso, que estas relaciones, que sin duda para él tuvieron escasa importancia, fueron menos duraderas y conocidas y, además no debieron tener consecuencias, le podían sin embargo costar su honra. Así lo vive él, y empieza a mover sus bazas de inmediato para que

“... se me volviese mi honrra, que solo eso pretendía y no otra cosa, porque quanto a el restituirme mi oficio yo no pretendía nada, antes desde entonces renunciaba la acción que a él tenia, y tambien renunciaba quantos oficios su magestad me podia dar y mercedes que me podía hacer, de las quales yo no tenia necesidad por las grandes que Dios me havia hecho aquel año haciendome señor de el mayorazgo y casa de mi Padre" (fol. 83).

De nuevo en su defensa actúa con la perplejidad de quien no entiende cómo se le puede echar nada en cara. Precisamente que se le acuse (justo cuando tiene por fin su primer hijo varón dentro del matrimonio) de algo que había 
pasado "siendo mozo y por casar". En un asunto que hacía ocho años que había sucedido, y para mayor asombro, siendo "que estas havian sido mugeres ordinarias de cuyo trato no podía haver escandalo ninguno" (fol. 78). Con todas ellas hacía muchos años que ya no tenía contacto, aunque de todas ellas pueda dar noticia pasado el tiempo. De hecho, incluso una ya estaba muerta y otra se había marchado enseguida a Sevilla, donde llevaba ya residiendo ocho años, y además casada.

$\mathrm{Y}$ en cuanto a haber cometido adulterio, es decir, haber tenido relaciones con una mujer casada, aunque siendo él soltero, lo negaba totalmente. Dice: "En quanto â la muger casada se provó ser enbuste y bellaquería y que desde que se caso con su marido siempre abian vivido juntos y en paz". Esta reacción tan enérgica de Gregorio tenía sentido, porque mientras que como soltero haber tenido relaciones con otra soltera, no podía ser considerado un delito, y como mucho le había dejado la obligación de resarcir a la moza económicamente, el adulterio era un delito, que tenía aparejadas serías penas que, aunque por lo general quedasen después algo aminoradas en su práctica, podían ser de muerte ${ }^{40}$.

La misma complicación le podía venir de haber mantenido relaciones con una mujer que en ese momento tuviera una causa en la cual él interviniera como fiscal en los tribunales.

"Provose tambien que ninguna de estas mugeres havia traido pleyto conmigo, y en los que ella traya con otras personas nunca yo la haber favorecido con los Alcaldes ni otros oficiales: ellos todos ansi lo dijeron y respondieron en sus dichos à instancia mia con juramento" (fol. 78).

En esta ocasión, Gregorio Tovar, que no creía tuviese nada que probar ni defender, solo tiene el recurso de desacreditar al visitador. Y lo hace atacando en todos los frentes. Por una parte, por su incapacidad para llevar a cabo una inspección en tan alto tribunal, cuando de todos era sabido que la Compañía de Jesús se había negado por estas razones a recibirle como visitador.

“...y cayó la suerte de hombre tan vil y mal christiano sobre aquella pobre Audiencia y se permitió fuese visitada por quien nunca havia sido oydor ni savido estilo ni ordenanzas y que a gente decía y savia los visitase un idiota, que ni aun palabra de latin ni la savia ni nunca supo; y haviendo antes de

\footnotetext{
${ }^{40}$ Margarita Torremocha Hernández, "Consideraciones jurídicas y sociales de la mujer adúltera en Castilla, a finales del Antiguo Régimen", Historia et Ius. Rivista di storia giuridica dell'età medievale e moderna (2016), $\mathrm{n}^{\circ} 9$.
} 
obispo sido Ynquisidor es público que al tiempo de el votar hacían burla de él sus compañeros" (fol. 79).

A todo ello se añadía la desfachatez de que el clérigo que había tenido una vida sexual más indecorosa se permitiera hablar de escándalo en un mozo "soltero y por casar".

"En fin por este escandalo causado de que siendo ya mozo y por casar traté con estas tres mugeres, merecí para en él estas penas olvidado él de que siendo mozo y aun despues de clérigo y obispo havia estado siempre amancevado y haver tenido tres hijos vastardos y ser como era hijo de clérigo y ansi según la mas opinión hijo de fraile, que despues vino a ser Arzobispo de Sevilla, y estando en la peor opinión y mas desonesto de quantos vivían" (fol. $\left.78 \mathrm{v}^{\circ}\right)$.

Sus quejas y expresiones difamatorias no eran más que una manifestación de un enfado, que era casi lo único que podía permitirse hacer. Por otra parte, esta terrible Visita afectó a casi todos los letrados del alto tribunal. De hecho otros muchos fueron también acusados y algunos corrieron peor suerte:

“...visto en otros de el Audiencia en unos cohechos, otros fuerzas, estupros, con trato ilícitos, tabernas, arrendamientos y otros excesos tales que ningunos se hallaren menores que los mios" (fol. 79v ${ }^{\circ}$ ).

Esta forma de protestar y exponer el "mal de muchos" deja claro que aquéllos que desempeñaban oficios en los tribunales, no siempre daban ejemplo de comportamiento en su vida privada ${ }^{41}$. Por ello, no duda en desacreditar también en esta misma línea a dos de los cinco consejeros que pasan a ver su causa tras la acusación efectuada en la Visita, y así dice:

"Ldo. Dn. Luys de Mercado, el qual olvidado de su vida pasada quando era oydor en la Chancilleria de Granada y lo que allí le sucedió con la muger casada en ofensa de su oficio y escandalo universal de todo aquel Reyno" (fol. 80).

el Lido. Tejada: el qual tambien olvidado de su mala vida pasada, por la qual siendo Alcalde de la Chancillería de Valladolid fue preso y llevado a la Villa de Pinto junto a Madrid y haviendo allí por sus delitos y excesos estado preso cinco años fue condenado en privación de el oficio de Alcalde quedando hecho un pobre catarribera, y yba a comisiones por no morir de ambre; el qual engañando al Presidente Cobarrubias que era buen hombre y sincero le

${ }^{41}$ Luis C. Amezúa, "Hacia una ética judicial del Estado Moderno. Las virtudes del juez según Pedro de Ribadeneyra”, Anuario de Filosofía del Derecho,19 (2002), p. 155-189. 
bolbió á su oficio y despues de allí â muchos días bino á ver del el Consejo Real. Este tenia una sobrina moza y por casar, con la qual quiso y deseo casar â DN. Thomas de Tovar mi sobrino que era el mayorazgo en mi casa: pusose este negocio tan adelante que estaban ya hechas las escrituras y el casamiento para efectuarse; lo qual como yo lo supe, hize quanto pude por lo desacer y ablando a mi sobrino de tal manera fue y le dije la verdad y causas por que no lo devia efectuar y quan mal le estava a él y á su casa y linaje que le dejó y se salió á fuera. Esto sintieron grandemente este licenciado Tejada y todos sus deudos, y callando él su boca hasta allar en que vengar de mi, aguardó á que yo le viniese â las manos, como fue agora, pues bino á ser mi juez y ansi vengó en mi su corazón=" (fol. 81 vº-82).

A la postre, estas relaciones con otras mujeres, a las cuáles él no había dado ninguna importancia en su vida, le pusieron en mayores aprietos que la relación estable y con descendencia, en la que sin embargo no había mediado palabra de casamiento. El visitador trató de aprovechar hechos probablemente ciertos, pero muy difíciles de contrastar pasado el tiempo. Hechos que Gregorio admite sin rubor en lo que a la moral respecta, pero que no puede asumir cuando se acercan al delito de adulterio o cohecho. Mujeres que ni tan siquiera considera, que aparecen imprevistamente en su vida para destrozar su carrera al servicio de la Monarquía.

En definitiva, unos retazos del relato de vida de un personaje concreto, a partir de una fuente controvertida de forma constante. El debate sobre si puede o no ser realista una biografía y más una autobiografía, y la interpretación de todos los límites que este género puede tener para su uso en la investigación histórica, atendiendo a la subjetividad de las representaciones, están ahí. Si bien las respuestas en la historiografía han sido contradictorias y heterogéneas, es obvio que este relato nos acerca a una vida particular que está inmersa y tiene una proyección del ambiente social en el que vive.

Sin duda su relato nos deja conocer algunas de las diferentes relaciones que Gregorio mantuvo con mujeres de todo tipo durante su gozosa etapa de soltería. Ello, nos permite ver otra vez los problemas que generaron unos tratos, sin palabra de casamiento. Lo normal era que estas promesas mutuas dadas entre hombre y mujer se hicieran bajo una perspectiva de género muy diferente, y permitían canjear honra y virtud por una promesa. Él obtenía el disfrute carnal y ella la esperanza de un futuro matrimonio. Gregorio es un letrado que sabe bien a lo que se obliga con estas palabras, y no las da, aunque Beatriz tampoco se las exige. Pero a la postre, las circunstancias de su vida le pusieron en la misma tesitura que si estas se hubieran dado. No se le puede incriminar de incumplimiento, pero sí de infamia y deshonra, aunque no llegó a ser acusado 
formalmente de nada, y los agraviados retiraron toda posible acción a cambio de una indemnización económica. Entran por tanto en un procedimiento común, cuando hay palabra, dado que se desenvuelven en un marco social en el que las relaciones premaritales están muy toleradas.

Así pues, este relato de vida nos permite conocer desde la microhistoria otra visión más de este fenómeno que marcó buena parte de las relaciones premaritales y de la litigiosidad entre solteros. Ver lo que era cotidiano en la vida de un varón que no estaba unido por vínculo matrimonial, que era libre y además no tenía problemas económicos. Estudiar sus relaciones con mujeres en su transcurrir cotidiano. Todo ello sin entrar en la atmósfera de sus sentimientos, descritos estos parcamente, y en no pocas ocasiones solo al hilo de cuestiones económicas o sociales que ocupan la primera línea de sus intereses. 